\title{
From Commission to Association: the transition of the International Commission on Snow and Ice (ICSI) to the International Association of Cryospheric Sciences (IACS)
}

\author{
H. Gerald JONES \\ Institut National de la Recherche, Scientifique (INRS-Eau), Université du Québec, 2700 rue Einstein, CP 7500, Sainte-Foy, \\ Québec G1V 4C7, Canada \\ E-mail: gerald.jones@videotron.ca
}

\begin{abstract}
The transition of the International Commission on Snow and Ice (ICSI) of the International Association of Hydrological Sciences (IAHS) to become the International Association of Cryospheric Sciences (IACS) within the International Union of Geodesy and Geophysics (IUGG) is described. IACS was accepted as the eighth Association of IUGG in 2007 and is the first new Association of the Union to be formed in over 80 years. Particular attention is paid to the reasons that prior to 1999 led to the request by the Commission to the Union for a change in status, and to the steps taken during the period 1999-2007 by the ICSI Bureaux and IUGG, that preceded the acquisition of Association status.
\end{abstract}

\section{COMMISSION OR ASSOCIATION? THE DEBATE 1927-99}

The International Commission on Snow and Ice (ICSI) began its existence in 1894 as the Commission Internationale des Glaciers (CIG) of the International Geological Congress. In 1927, CIG became a Commission of the International Association of Scientific Hydrology (IASH; later the International Association of Hydrological Sciences (IAHS)) of the International Union of Geodesy and Geophysics (IUGG). The Commission joined with the Commission on Snow of IASH in 1939 to become the Commission on Glaciers and Snow, which ultimately took on its final title in 1948.

The centennial celebrations of ICSI took place in Innsbruck, Austria, in September 1994, and shortly thereafter Radok (1997) chronicled the history of the Commission through its first 100 years and the fin de siècle. Radok, President of ICSI from 1975 to 1979, described the significant scientific contributions that the Commission had made to international programmes such as the International Geophysical Year (IGY) and the International Hydrological Decade (IHD) of UNESCO. He also gave particulars of the work of the Commission on many of the fundamental phenomena in glaciology and cryospheric science, such as the cryosphere and climate change, glacier fluctuation, and snow physics and chemistry, through conferences, workshops and working group reports. These activities, in addition to the collection and archiving of data on glaciers by the World Glacier Monitoring Service (WGMS; under the responsibility of $\mathrm{ICSI}$ ) and various training programmes in technology transfer, ranked ICSI as a very productive and valuable Commission of IASH/IAHS during these years.

However, Radok also alluded to certain problems that $\mathrm{CIG}$ and ICSI had faced in carrying out their mandate within IASH/IAHS. In particular, he recorded that at the Sixth General Assembly of IUGG at Edinburgh, UK, in 1936, Dobrowolski, the Vice-President of the Glacier Commission and author of the first modern glaciological textbook, presented a paper (Dobrowolski, 1938) which proposed the creation of an Association of Cryology (Association de
Cryologie). Radok further commented that this was 'an idea that has resurfaced repeatedly since then without being accepted'. He did not, however, go into any more detail.

It is instructive to examine Dobrowolski's arguments and the reaction to them, as they expressed many of the ideas that were the subject of debate in later years. In his publication, Dobrowolski focused his arguments in favour of the proposal on three main points: the universality of ice, the singularity of ice and the methodology of the study of ice. The first point relates to the fact that ice is the most widely distributed solid component of the Earth's surface. This wide distribution of ice in air, on water bodies and on and within the land surface can be considered as an envelope called the cryosphere comparable to the other envelopes of the Earth the atmosphere, hydrosphere and lithosphere. Secondly, ice has remarkable characteristics due to its triple point. At the prevailing amplitude of temperatures in the atmosphere and on the Earth's surface, this leads to the appearance, disappearance, growth and decline of ice with the absorption and liberation of energy over extremely short periods of time compared with other solid bodies. Ice is thus found at the centre of a large number of physical, mechanical and morphological phenomena occurring on the planet at all scales, from the global/continental to the microscopic. The third and final point held that ice is studied by methods in mineralogy and petrology that are much more characteristic of research into the solid bodies of the lithosphere than methods used in the study of water in the liquid phase (hydrosphere) and water vapour (atmosphere).

Dobrowolski further elaborated on these points to justify his proposal that cryology should be recognized as a science distinct from hydrology and meteorology. He recognized, however, that the three disciplines were closely related. He concluded by stating that as research into the hydrosphere and research into the atmosphere were represented by Associations of IUGG (IASH and the International Association of Meteorology (IAM; later International Association of Meteorology and Atmospheric Sciences (IAMAS)), then the logical step would be for IUGG to create a separate Association for the study of the cryosphere. 
At the Edinburgh General Assembly, Dobrowolski also attended the IASH Executive Committee meeting to officially present his proposal for the creation of a separate Association of Cryology (AIHS, 1936). His proposal failed to attract any support. The counter-arguments were not so much scientific as practical and organizational. The reasons for rejecting his proposal were many. Amongst those recorded in the minutes of the meeting were the apprehended objections of other IUGG Associations based on financial considerations, and the opinion that IUGG would in any case reject any modifications to the IUGG statutes at that time. The IASH Executive Committee also resorted to arguments that concerned its own Association. These included the point that the proposed Commission of Snow and Ice, which was under discussion at that time, would be adequate to carry out scientific investigation in all areas of the cryosphere. In addition, the efforts to form a new Association would disperse the activities needed to consolidate the work of IASH, and finally there was apprehension regarding the impact on hydrology as a science if ice was to become associated with another discipline.

From an examination of the Dobrowolski proposal and the discussions surrounding it, it might appear that his wellthought-out scientific justification for creating an Association to study the cryosphere was countered by a response with more bureaucratic overtones than scientific content. However, one should bear in mind the context of the times in which these events took place. For example, IUGG Associations were financially strapped and complained of insufficient funds to carry out their mandates. The practical operations in the organization of scientific bodies and their activities, particularly at the international level, were hampered by the relative paucity and slowness of communications in those days, so time would also have been a major constraint. Bureau positions except that of the Secretary-General were only occupied for one or two terms, and the demands that would have been placed on the Bureau Officers by an effort to create a new Association would certainly have affected the activities of IASH. Another major factor was the prevailing view among many of Dobrowolski's colleagues in IASH/IAHS and elsewhere that glaciology was a sub-discipline of hydrology. This stemmed in part from the practical aspects of Earth science related to the exploitation of natural resources, which were of major interest in the periods both before and after World War II. Ice was considered as water naturally held in reserve for the purposes of power production, flood control, inland navigation and the irrigation of agricultural land, all of which, particularly in Europe, were chiefly the domain of the hydrological sciences. Although global problems such as the relationship between climate change and glacier fluctuations were recognized even at the time of the creation of CIG, the scope of research on glacier ice in IUGG tended to be focused around the discipline of its Association of Hydrological Sciences.

After the 1936 IUGG General Assembly, World War II effectively brought an end to IUGG international activities until 1948. The question of a separate Association for the study of the cryospheric sciences began to be debated again after the war, however, (Dobrowolski, 1951), and in 1958 at Chamonix, France, the ICSI Bureau adopted recommendations to organize such an Association within IUGG. This was the prelude to a request by the USSR National IUGG Committee to the IAHS Bureau to address the question of forming a separate Association for glaciologists or giving them more independence within IASH (IASH, 1960).

The reasons for the request are outlined in a letter appended to it, entitled Recommendation to organize the Association of Glaciology within the IUGG', by Professor G.A. Avsjuk of the USSR National Committee of Geodesy and Geophysics. The terms cryology and cryosphere do not appear in the letter, but the arguments used to support the proposal were similar to those of Dobrowolski. However, the wide scope of glaciological phenomena and the methods of study of fundamental problems that particularly arose during the IGY period 1957-59 gave new impetus to the issue. The letter noted that fundamental interrelationships (e.g. between climate and ice, ancient ice formations and geological activity, and Earth evolution and ice formation) required consolidation of the efforts of glaciologists and cooperation on an international scale. The existing forms of international scientific cooperation in glaciological research by ICSI within IASH were judged to be inapt for coping with the tasks of modern glaciology, as its tasks and methods went beyond hydrological approaches to the phenomena under study. In response to the Soviet request, the American Geophysical Union (AGU) Committee on Glaciers took the opposite line, i.e. that glaciologists should press for retention of glaciology in IASH because to split off would cause immediate practical difficulties and an unnecessary proliferation of organizations. The Soviet proposal never came to fruition.

However, the debate continued through the 1960s-80s, within a changing context. Research on the physical dynamics of ice and the fundamental relationships between the cryosphere and the evolution of the other component systems of the Earth and climate came more and more to the fore. The need for multidisciplinary research emerged, as the scope and complexity of the phenomena became known. Glaciology and the study of the cryosphere within IAHS, however, were still heavily slanted towards the discipline of the Association, and there were growing calls for a new Association to act as a forum for the scientific community engaged in all fields of cryospheric science. A study of the minutes of ICSI Bureau meetings confirms that the issue and/or the problems associated with it arose frequently over the years (e.g. in 1987, 1988, 1990, 1992 and 1994).

IAHS was also becoming more aware of the problems faced by its Commission. Louis Lliboutry, President of ICSI 1983-87, was particularly concerned that many glaciologists in fields other than the hydrology of snow and ice were not attracted to ICSI sessions during IAHS Assemblies. He attempted to rectify this by proposing that the ICSI regulations allow the Commission to include representatives from and in other Associations and bodies of its own choosing. The ICSI Bureau surmised that this autonomy to interact with other institutions of the glaciological community would enable ICSI to better cover its mandate in all branches of glaciology and to consolidate this position by increasing the participation of glaciologists in nonhydrological fields. These latter glaciologists often participated more in the symposia of other Associations of IUGG, such as IAMAS and the International Association of Meteorology and Atmospheric Sciences (IAPSO), than in those of IAHS. IAHS accepted the ICSI proposal (ICSI minutes 1992), and the ICSI regulations were subsequently modified. However, the expected results did not materialize. As early as 1989 it appears that the efforts being made in this 
direction were not equally responded to by other associations, as they failed to send their representatives to ICSI Bureau meetings (ICSI minutes 1989).

The glaciological community was thus fragmented within the IUGG structure, and ICSI became caught in a vicious circle. The less the non-hydrologists participated in ICSI, the more ICSI/IAHS tended to cater to the hydrological aspects of the cryosphere, which led in turn to a further decrease in the interest of their colleagues active in the non-hydrological aspects of cryospheric research. In addition, the success of the IHD/International Hydrological Program (IHP) glacier and snow-cover programmes contributed to narrowing the focus of the Commission's area of interest to snow and glacier runoff. ICSI was having great difficulty in fulfilling its mandate - 'the advancement of the study of naturally occurring snow and ice' (ICSI terms of reference) - in fields other than hydrological studies. This situation highlighted the apprehensions that Dobrowolski and others had expressed over half a century previously.

At the ICSI centenary celebrations in Innsbruck on 14 September 1994, Mark Meier, President of ICSI, 196771, gave a keynote speech on the progress of ICSI through symposia and publications over the years leading up to the centenary. He emphasized the rapid expansion of science in recent years and foresaw both a problem and an opportunity in the future evolution of the Commission. He developed a clear and succinct analysis of the direction that ICSI symposia were taking within the rapid changes and opportunities in international science. He showed how the Commission's trend to focus primarily on the discipline of hydrology ran contrary to the new realization that the Earth system transgresses conventional scientific disciplines. He encouraged ICSI to participate in the development of a new approach, a new paradigm of science in elucidating the role that snow and ice plays in the dynamics of the atmosphere, the surface of the land, the oceans, the solid Earth itself and the biosphere. On the other hand, Meier discussed the difficulties of taking part in a new and multidisciplinary context of Earth science when the hierarchy of scientific bodies is organized along disciplinary lines. Could ICSI fully participate in IAHS, and IAHS actively support ICSI, when ICSI's interests were so wide-ranging outside the field of hydrology?

\section{THE PATH TO ASSOCIATION STATUS: FROM DEBATE TO DECISION, 1999-2007}

Meier's presentation set the tone for much of the subsequent debate in the late 1990s. The consensus among ICSI Bureau members and many of their colleagues was that an association of cryospheric sciences would offer a forum to the glaciological community and facilitate the integration of glaciology in the directions that the study of the Earth and its component systems was taking. However, the debate remained mainly theoretical. There was little discussion on any precise steps to achieve this change in statute for the Commission, and the negative experiences of past attempts clouded the issue. On the other hand, the scientific context had changed considerably over the years. The role of the cryosphere in climate change was now at the forefront of international science, new methods of study were evolving rapidly, and many thought that the time was now opportune to revive the issue of a new forum for researchers on the cryosphere within IUGG.
In 1999 a new ICSI Bureau was elected at the 22nd IUGG General Assembly in Birmingham, UK. At the Bureau meeting in March the following year, the officers agreed that the Commission would pursue a course of action that could lead to a change in status of the Commission. The ICSI President-Elect (1999-2001), H. Gerald Jones, was requested to coordinate the steps that the Bureau deemed necessary to prepare the proposal for submission to IUGG, and any subsequent measures that would be required to assure the transition from Commission to Association.

The first step was to prepare a document entitled 'The Status of the International Commission of Snow and Ice (ICSI) within the IUGG structure: a discussion paper for the ICSI Bureau'. The paper, submitted to the ICSI Bureau at the Sixth Scientific Assembly of IAHS at Maastricht, The Netherlands, in 2001, examined the problems experienced by ICSI in carrying out its mandate within IAHS, and explored the organizational options that lay open to the Commission to alleviate these problems. The paper concluded that the best status that ICSI could attain to execute its mission of representing the glaciologists of all fields would be that of an Association of IUGG, and proposed a procedure and timetable for the publication of a position paper on the means to achieve Association status. The position paper had to be a collective effort on the part of the ICSI Bureau in collaboration with prominent glaciologists from outside the Bureau, and with the support of organizations from the international glaciological community, notably the International Permafrost Association (IPA) and the International Glaciological Society (IGS). It also had to gain the approval of the IUGG Associations, particularly IAHS. After accepting the discussion paper, the Bureau presented it for consideration to the ICSI Plenary at Maastricht and to the President of IAHS.

ICSI pursued its consultation with various researchers and organizations during 2001-02. Counsel was sought from glaciologists on their perception of how ICSI could achieve its objective within the time frame of one or two IUGG periods, and the ICSI President tabled a position paper on behalf of the Bureau in May 2002. In March 2002, IPA and ICSI selected a task force to examine issues of common concern and collaboration and to present any recommendations on the status of ICSI within the ICSU structure that would permit ICSI and IPA to coordinate their efforts in reaching out to the glaciological community at large. The subsequent report tabled in January 2003 included the recommendation that the IUGG approve and implement Association status for a new International Association for Cryospheric Sciences (IACS). In 2002-03, ICSI also maintained close contact with IGS; the IGS President, Elizabeth Morris, strongly advocated that an IUGG Association of Cryospheric Sciences and IGS could and should play complementary roles in the science of snow and ice. IACS as a member of the IUGG structure would have responsibilities and activities that would complement those of IGS as an independent scientific organization. In February 2003, IAHS, through the offices of the Secretary-General, Pierre Hubert, indicated support for the course that the ICSI Bureau was pursuing, and in March 2003 the ICSI Bureau submitted 'A proposal that the International Commission on Snow and Ice (ICSI) attain Association status within the IUGG structure' to IAHS and the IUGG Executive Committee at the 23rd General Assembly at Sapporo, Japan. The proposal presented many of the above points for the recognition of 
glaciology as a discipline as defined by IUGG and thus worthy of Association status. It emphasized that the cryosphere plays a role that necessitates studies as wide-ranging and as comprehensive as those of any of the other dynamic Earth systems, namely the atmosphere, hydrosphere, lithosphere and biosphere. Reference was made to programmes on the large-scale interactions between the cryosphere and other Earth systems, such as the Climate and Cryosphere project (CliC; World Climate Research Program (WCRP)/ World Meteorological Organization (WMO)), Arctic Climate System Study (ACSYS; WCRP/WMO), the associated Mass balance of Arctic Glaciers and Ice Sheets in relation to Climate and Sea level changes (MAGICS; International Arctic Science Committee (IASC)) and the Greenland Icecore Project (GRIP; European Science Foundation). In addition, worldwide satellite observations of the cryosphere by satellite, including CryoSat (European Space Agency) and Global Land Ice Measurements from Space (GLIMS; United States Geological Survey), reflect the recognition of the cryosphere as a major factor in global change.

The IUGG Executive Committee responded positively. The members requested that ICSI prepare a plan of action that would detail both the steps and a timetable to achieve the goal of an Association, particularly with reference to defining the objectives of the future Association and the means of communication and international cooperation in promoting its mandate. The response also included the understanding that ICSI could be asked to become an interim inter-Association Commission in order to allow time for the Associations to consider the impact of an eighth Association on the Union's structure (IUGG Executive Committee minutes 2003). The plan entitled 'The International Commission on Snow and Ice (ICSI): a Plan of Action submitted to the Executive Council of the International Union of Geodesy and Geophysics (IUGG) with the view to attaining the status of an association within IUGG' was completed and submitted to the IUGG Secretariat in March 2004. The plan covered the period 2003-07. It defined the objectives of the new Association and the realization of the objectives through activities regrouped in three main fields, namely 'The Science', 'Structure and Administration' and 'Service to the Community'. 'The Science' included the organization of major scientific meetings, the promotion of global scientific programmes, and the relationships with international, national and regional scientific bodies in glaciology and the cryospheric sciences. 'Structure and Administration' described the following activities and timetables: the definition of 'Statutes and Bye-laws, 2006', the consolidation and expansion of the 'National Representatives Network, 2004-2007' and the 'Finances for ICSI Bureau' activities during the interim period, 2003-07. 'Service to the Community' included 'Service to the International Scientific Community' (WGMS) and 'Service to the Community-at-large' (science in the service of society).

The IUGG Executive Committee meeting in Boulder, CO, USA, in September 2004 approved the plan of action for consideration and ratification by the IUGG Council at the 24th IUGG General Assembly in Perugia in July 2007. In the meantime, the IUGG Executive Committee voted unanimously to accept ICSI as the Union Commission for the Cryospheric Sciences (UCCS) until the IUGG Council meeting. The Executive Committee also requested that UCCS draw up statutes and bye-laws for the future Association in conjunction with the IUGG Secretariat. The IACS statutes were drawn up in July 2005, accepted with minor modification by the IUGG Executive Committee in September 2005 and submitted to the IUGG Council in February 2007.

On 4 July 2007, the IUGG Council voted to establish the IACS as the eighth Association of IUGG. It was the first new Association to be formed in over 80 years.

\section{ACKNOWLEDGEMENTS}

I acknowledge the support, encouragement and active participation of the two ICSI Bureaux (1999-2003 and 2003-04) and the UCCS Bureau (2004-07) in the preparation of the documents mentioned in the text. The ICSI Bureau Officers of 1999-2003 were E. Morris (President, 1995-2001, Past-President, 2001-03), G. Jones (PresidentElect, 1999-2001, President, 2001-05), G. Kaser (Secretary), E. Brun (Vice-President), J-O. Hagen (Vice-President), D. Qin (Vice-President), M. Lange (Head, Division of Sea, Lake and River Ice), J. Dowdeswell (Head, Division of Glaciers and Ice-Caps), P.I Föhn (Head, Division of Seasonal Snowcover and Avalanches), T. Hondoh (Head, Division of Ice as a Material) and W. Haeberli (Director, WGMS). The ICSI Bureau Officers of 2003-04 and UCCS Bureau Officers of 2004-07 were G. Jones (President, 2001-05, Past-President, 2005-07), G. Kaser (PresidentElect, 2003-05, President, 2005-09), P. Jansson (Secretary), K. Steffen (Vice-President), J-O. Hagen (Vice-President), K. Goto-Azuma (Vice-President), M. Lange (Head, Division of Sea, Lake and River Ice), J.Dowdeswell (Head, Division of Glaciers and Ice-Caps), C. Fierz (Head, Division of Seasonal Snowcover and Avalanches) and W. Haeberli (Director, WGMS). The position of Head of the Division of Ice as a Material was vacant.

The ICSI Bureau is indebted to colleagues in the glaciological community for supporting and collaborating with the Commission in its efforts to achieve Association status. R. Barry chaired the ICSI-IPA task force. He also contributed greatly to the preparation of the documents for ICSI, IAHS and IUGG and assisted the President and President-Elect of the Commission during the IUGG hearings in 2003 and 2004. Many other prominent members of the glaciological community, including M. Meier, A. Ohmura and R. Alley, offered counsel for the preparation of and/or reviewed the different documents required by IUGG. Finally, the ICSI Bureau wishes to thank both IUGG and its Associations for their encouragement and understanding of the Commission's aims, particularly during the 4 year period prior to the 24th IUGG General Assembly at Perugia. The invaluable help of P. Hubert, IAHS Secretary-General, is gratefully acknowledged, and the support and counsel of R. List, IAMAS Secretary-General, is also recognized. In addition to the wishes of the Bureau, I would personally like to thank J.A. Joselyn, IUGG Secretary-General, for her significant contributions to the formulation of the IACS statutes and bye-laws.

\section{REFERENCES}

Association Internationale d'Hydrologie Scientifique (AIHS). 1936. Séance du Comité executif du 14 Séptembre. AISH Bull., 22, 641-645.

International Association of Scientific Hydrology (IASH). 1960. Section 2, Commission des Neiges et des Glaces/Commission 
on Snow and Ice, item b. Letters of USSR concerning glaciology/ Lettres de I'URSS concernant la glaciologie. IASH Newsl., 18, 37-39.

Dobrowolski, A.B. 1938. Sur le problème de la réalisation d'une organisation cryologique internationale. IASH Bull., 23, 65-75.
Dobrowolski, A.B. 1951. Commission, ou bien Association? 'Des Neiges et des Glaces', 'de Glaciologie' ou bien 'de Cryologie'? IASH Bull., 32, 142-144.

Radok, U. 1997. The International Commission on Snow and Ice (ICSI) and its precursors, 1894-1994. Hydrol. Sci. J., 42(2), 131-140. 